\title{
INTEGRATED LANGUAGE LEARNING IN ESTONIAN NATIONAL CURRICULA (NC) FOR GENERAL COMPREHENSIVE SCHOOLS
}

\author{
Urve Läänemets \\ Katrin Kalamees - Ruubel
}

Tallinn, Estonia

\begin{abstract}
Multiple language skills have become a critical issue in the globalised world. The EU education strategy 2020 document includes mother tongue and two foreign languages among its key competencies to be achieved. To promote learning with comprehension, an integrated approach to curriculum design can be taken, including a cycle of language subjects that makes use of both the manifest and hidden curricula as well as different learning environments. The $21^{\text {st }}$ century approach to education requires from all school staff not only technical but considerable intellectual competence. Language learning is expected to meet the regional and local demand for particular language skills, which is determined by regular monitoring according to functional styles.
\end{abstract}

Keywords: national curricula, hidden curriculum, linguo-didactics, integrated content of learning languages, syllabus design, learning environments, teacher competencies.

\section{Introduction}

Language proficiency has always been a valued skill. Ludwig Wittgenstein famously wrote in his "Tractatus Logico-Philosophicus": "The limits of my language mean the limits of my world." Although the scholar was referring to the scope of individuals' mental horizons as determined by the size of their vocabulary in their mother tongue - meaning their ability to describe and comprehend the world around them - the current needs for wider communication skills in all societies have led to new educational developments. The rational acquisition of language skills has been a significant research problem since the second half of the $20^{\text {th }}$ century, and is still important for all educational systems today.

The organisation of language learning has been recognised as a critical issue in almost all national and European educational policy documents, and is often specified as a component of IDE (International Dimension in Education); it is included in the new Erasmus+ program and has been discussed in several articles (e.g. Davies, 2014). Acquisition of skills in several languages has been clearly designated in the EU Education Strategy 2020 document, in which competence in three languages - the student's mother tongue and two additional 
foreign languages - has been listed as one of the eight key competencies to be achieved in the process of life-long learning (EU Strategy, 2020).

In today's globalised world the need to understand people from different cultures has made multilingualism an unavoidable requirement for all societies. Allardt stated that multiple language skills were particularly important for small nations (Allardt, 1979), which he considered as destined to be multilingual. For such countries, mother tongue skills often mean preservation of a particular linguistic culture and serve as a basis for establishing and defining individual and group identities (Läänemets \& Kalamees-Ruubel, 2015).

Popular slogans undoubtedly reflect recognised aspirations towards lofty and desirable goals, but real life with its social, political, and cultural problems requires solutions - in most European countries regarding compulsory school education - meant to provide the whole population with adequate communication skills. Accordingly, language policy documents, NC for compulsory schools, and studies of the context for language learning deserve particular attention. Such materials and documents organise and guide language learning, and usually include one or more foreign languages in addition to mother tongue in curricula for different levels of educational institutions.

The aim of this article is to examine the opportunities for developing integrated language syllabi for compulsory school NC in order to identify the most rational approach to organising language learning for the whole population. Research data in different fields can be used, such as regular monitoring of the functional use of languages in a region or country that specifies the demand for skills in various languages; the potential of compulsory schooling in a particular socio-political context, a country's past experience related to the acquisition of language skills (especially curriculum development and principles for the organisation of learning languages), taking into account its traditional educational culture and the role and requisite quality of teacher training.

The methods used for this study are document analysis, which included Estonian language policy documents and the curricula for Estonian general comprehensive schools, essays $(n=972,2013)$ on teacher competencies, questionnaires for determining the functional use of languages $(n=746,1989)$, and the study of Content and Language Integrated Learning (CLIL) developments in Estonia (Läänemets \& Valdmaa, 2015). Two recent $\mathrm{PhD}$ studies are of particular relevance - Katrin Kalamees-Ruubel's on the role of Estonian and literature in Estonian NC 1917-2014 (Kalamees-Ruubel, 2014), and Anu Sepp's on the development of teachers' thinking skills (Sepp, 2014). Theoretical views of Sowell (2005), Slattery (1995) and Karseth \& Sivesind (2011) have been used for analysis of curriculum design and the selection of the content. 


\section{Language policy}

The language policy of a particular society or country sets the stage for language learning. According to Schiffmann, such policies are based on the linguistic culture (Schiffmann, 1995). The selection of languages and their functional use in specific social, political and economic contexts is regulated by the country's language laws, strategies, legal documents specifying the role of different languages and their coexistence, and represents a combination of language ideologies (Krzyzanowski \& Wodak, 2011, 118). According to Blommaert, ideologies usually express how the community perceives the functional value of different language skills in its everyday activities (Blommaert, 2006). Estonian language policy, as an important factor that to a large extent determines the educational policy, reflects the languagecenteredness of our ethnic culture, in which the Estonian mother tongue has a particularly active and meaningful role.

Historically, the language policy of many countries has been designed and implemented for the protection of the state or national language in all spheres of social life, and this has also been the case in Estonia. Even considering current globalisation processes, the importance and meaning of a mother tongue cannot be ignored. Accordingly, language policy must be based on the dominant local culture and recognise the different layers of the languages used in a particular society, which in Estonia means the leading role of the Estonian language and culture. According to Lotman, "languages are never passive factors in the formation of cultures, and he also underlines the meaning of living languages as models of the world"' (Lotman, 1990: 48).

However, Estonian language policy documents since independence was regained in 1991 have paid more attention to the development of state language skills for those whose mother tongue is not Estonian, and have idealised the language immersion method (cf. language acts, language strategies, specification of language skills in job requirements, etc.). At the same time, the influence of globalisation on the culture, so aptly described by Holton (Holton, 2000: 146) has not been considered a critical issue with regard to linguistic balance and the protection of diversity. The processes of homogenisation (usually called Westernisation, or, more accurately, Americanisation), and the mix and polarisation of different cultures, have been neither researched nor analysed as factors that influence educational policy with regard to language learning in the Estonian context.

The concepts of literacy and language fluency have also changed, specifying not one but several different kinds of literacy (computer literacy, business literacy, etc.) that are fostered by social networks. This leads to sociolects - using terms that differ greatly from language norms and accepted 
registers. In addition, the term "command of a language" often means only limited language skills nowadays, which involve simple communication at a basic level and the increasing use of so-called mixed language. At the same time, there are internationally recognised exams specifying the precise level of language proficiency of an individual according to the European Framework, which makes the organisation of language learning even more complicated for general comprehensive education, especially in the light of students' highly diverse abilities.

Although it is very challenging to develop a rational language policy, Latvia deserves positive recognition for guaranteeing the status of the state language and preserving minority languages by establishing a judicial hierarchy of languages. Three elements of fluency in the state language have been designated: language skills, language use, and attitudes. A basic comprehension of Latvian is not considered sufficient. All residents are expected to be capable of the "practical" use of Latvian (Balodis et al, 2012: 5-7), which recognises the role of the language as a basis for national identity and the means of integrating the society for future generations. The policy also describes the responsibility of the state to protect Latvian as a cultural phenomenon. (Guidelines of the State Language Policy for 2005-2014, 2005).

It must be acknowledged that the 21st century was characterised by controversial and parallel tendencies that mutually influenced each other. The first is a perceived need to accept common values arising from the processes of globalisation; the second aspires with the aim of avoiding complete uniformity ethnic identity and the diversity of cultures that enrich the world cultural heritage. Both tendencies are necessary for the social cohesion and sustainability of a society. The organisation of national education deserves particular attention under such circumstances. We have to understand the cultural space in which the school is situated, the opportunities for development, and the prospect for creating a cultural space for the future (Läänemets, Kalamees-Ruubel \& Sepp, 2011: 138). It is therefore important to consider all the options as well as the limitations within a society for organising language learning. Language learning is a political as well an educational and cultural issue that greatly influences the socialisation of an individual and the development of a cohesive society by shaping the content of education. For this reason, the NC for general comprehensive schools and the language syllabi they contain deserve particular attention as tools that give the entire population of a society access to language learning. 


\section{Organisation of language learning at different times}

For purposes of analysis, Estonian curricula for general comprehensive schools can be clearly divided into three periods: 1917-1940, 1945-1991, and from 1991 to the present. Such curricula usually contained three or more language subjects in addition to other traditional school subjects such as math, science, music, and social studies (Läänemets, 1995). This indicated aspirations towards multilingual skills that took into account the demographics and three local spoken languages (Estonian, Russian, and German at the beginning of the $20^{\text {th }}$ century). Since the 1930s English emerged as a new and popular foreign language and foreign-language-learning priorities shifted to reflect the political changes that were creating new contexts for different languages.

All language learning as well as the other school subjects from 1917 to 1991 were based on mother tongue as the foundation of all learning and personality development. Language subjects made use of literature in the respective languages. Reading Estonian literature, and also European and world classics, was designed to enlarge students' vocabulary and develop their expressive skills; its most valuable result was reflected in a wide knowledge of other cultures (Kalamees-Ruubel, 2014). The foreign languages (FL) learnt also included Latin as a compulsory subject at the gymnasium level until 1940. Also later, teachers were advised to use the language concepts acquired in the mother tongue for learning FL, which were linked to school subjects. Although this predated educational theories of integrated learning, linguo-didactics, etc., learning with comprehension, was already practiced in those days. Learning objectives were clearly set for different levels and oriented to comprehension of the language (primarily reading texts, but also listening to dialogues over the radio, etc.), then to speaking, and to writing (letters, essays, paraphrases). Setting this type of goal was justified in those times, as people had limited opportunities to travel.

As the languages themselves do not have any independent textual content, texts used for learning foreign languages had to be taken from different walks of life, which provided cultural information about the countries where the respective languages were spoken (termed Landeskunde for German and Country Studies for English). Moreover, literary texts that presented the language in its artistic and most enjoyable form were widely used, complementing the works read in Estonian literature lessons with new examples (often adapted) by authors of classics. Nevertheless, students were also expected to be able to discuss everyday topics, know the communication etiquette, and the use of registers. All language syllabi (called programmes in Soviet times) also contained lists of language structures (grammar concepts, etc.) to be acquired. Methodological recommendations for teachers were published as additional 
materials. The study aids were comprised of textbooks, literary works, grammar handbooks, tables, pictures, and travelogues (mostly for foreign languages). The language-learning aims for different levels of schooling, expected learning outcomes, as well as recommendations for assessment were precisely specified. The role of the mother tongue was highlighted and designated as the first school subject to be learned. The development of educational programmes for language learning (language syllabi) from 1945 to 1991 was a local responsibility, as it could not be prescribed at the pan-union level. Extra-curricular activities were widely employed. In 1984 a department of linguo-didactics was established at the Estonian Research Institute for Education, which undertook a well organised and scientifically sound school experiment on language subjects. The last research data were collected in 1991, after which the institute was amalgamated with the Tallinn Pedagogical University.

The syllabi for learning Estonian as a mother tongue in the NC of 1996, 2002 (which contained a new introduction, but the same subject syllabi as the 1996 version), and 2010 feature new approaches, by which many decisions about the time allotted for learning, and the selection of the content and methods were all made the responsibility of schools. The increased freedom was welcomed, but not all the changes made at various levels were well planned and/or implemented. The hidden curricula and other supportive learning environments, which are particularly influential for language learning, including the potential of ICT, have not been taken into account on a professional level. The compulsory number of language lessons has diminished at all school levels, particularly with regard to learning Estonian as a mother tongue (since 1978 the number of lessons has decreased by $c a 500$ ).

The number of foreign language lessons has also decreased, although schools try to use the time provided for optional subjects mainly for learning English, especially in light of the introduction of national exams in 1997. At present, a foreign language exam has become compulsory (to be taken at either the national or international level). In the most recent NC Estonian is listed separately from foreign languages (English, Russian, German and French), and the content for all languages has been considerably abbreviated. Neither the systematic acquisition of language structures nor literature, are mentioned in the common syllabus for learning foreign languages, which is expected to suit the study of all the mentioned languages equally well. Although the goal of integrating school subjects to create a meaningful whole for comprehending the world and socialising the individual has been expressed in the general part of the $\mathrm{NC}$ for compulsory schools and gymnasia, it can only be achieved to a certain extent at the school level, if teachers are able to collaboratively develop school curricula for practical implementation. However, the practice of integrating 
language learning according to the principles of linguo-didactics can be revived and used for future professional curricula and syllabi design.

\section{Linguo-didactics and integrated language subjects in the Estonian National Curricula}

It is common knowledge that the content selected for learning has to be organised, usually according to school subjects. These represent specific fields of human knowledge that are considered worthwhile to transfer to new generations at particular times and in prevailing socio-political contexts. In order to learn with comprehension, it is rational to combine similar or closely related subjects into one cycle (languages, sciences, etc.). Such an approach improves both the selection of the content and the organisation of the learning process. Syllabi for learning languages and acquiring the skills of independent text comprehension and language production can be designed to respect distinct logical sequences of the subject matter. According to Pring, certain kinds of knowledge presuppose others of different kind, and there is a need, in designing a curriculum, to work out, what presupposes what (Pring, 1976: 104). Basing the learning of all subsequent languages on the concepts and structures students acquired in learning their mother tongue makes such learning easier and produces the desired results. Of course, one needs to consider language interference, which can have both positive and negative effects, especially on vocabulary and sentence structure. However, integrated language learning makes the most advantageous use of the time allotted for learning and enables students to apply their previous life experience to developing their language competencies.

The discipline of linguo-didactics was initially implemented in the design of foreign language syllabi in Estonia in the 1970s following the publication of articles by Reinecke (Reinecke, 1978) and Leino (Leino, 1979); considerable research was also undertaken in Lithuania and Moscow (Zimnjaja, 1978). All of the research stressed the value of good mother tongue skills for learning foreign languages: the basic principles included the use of common concepts, logical sequencing of the learning content, consideration of language interference, and the development of the students' cultural horizons. An experiment to test the approach in Estonian schools was conducted in 1984. Although Kampmann had established principles for learning Estonian as a mother tongue in 1918 already (Kampmann, 1918) and had made the first attempt towards integration by using both vertical and horizontal approaches to selecting the content and organising the learning process, his pedagogical milestone has not been applied to learning Estonian as a mother tongue since 1945. 
The analyses of curricula and language syllabi undertaken in this study have shown that the content of learning can and should be organised again in a logical and integrated way by using basic common concepts (parts of speech, tempora, syntax, etc.) and presenting them in a sequence that will lead to comprehension of language phenomena and the understanding of how to use them in practical communication in particular functional fields. There are so many opportunities to make connections with different school subjects; however, what is being integrated, how it can be done, and why it is desirable need to be clearly understood. Integrated content for learning different languages considering mother tongue as a basis and the use of common linguistic and cultural phenomena of all languages (Byram, 2008, Joseph, 2004) can be presented in curricula and syllabi. However, the integration of the learning process greatly depends on the teachers' pedagogical skills. Recent studies have shown that students expect teachers to demonstrate and explain the relationships between school subjects and their real-life applications. For example, students valued highly the use of common language concepts and cultural knowledge (Läänemets, et al., 2012, Sepp, 2014). The use of the hidden curriculum in a particular society (e.g. the influence of English) and extracurricular activities can support meaningful learning, especially language learning, if one makes use of media and organised cultural events as learning environments. Despite the progress of ICT, it is well understood that computerbased learning has to be balanced with other forms of study in which teachers intellectual skills are of crucial importance (Kalamees \& Läänemets, 2012). Moreover, in order to develop students' wider comprehension of different environments (especially social and cultural), the process of learning literature and languages should be varied, which also provides more opportunities to accommodate students with different learning styles and capacities. (Kalamees, 2014: 217).

It needs to be acknowledged that language never copes very successfully with rapid social change. New fields of human activities overwhelm the world of words, and sometimes we lack words for describing new phenomena, or we do not understand the context. The daily use of the language commonly used on electronic devices has greatly changed our students' text production skills. Abbreviations, icons instead of sentences, and limited vocabulary are not mere fashion phenomena. They are also indicative of a limited capacity for denoting and comprehending the world. For this reason, reading and using standard language have come to the foreground. Skilled reading has much value in contemporary society, and adults without effective reading skills are at a great disadvantage. (Eysenck \& Keane, 2005: 322). Reading is essential because it helps initiate young people into the existing culture, which must be transmitted. 
If such contacts do not take place, and if a student does not learn from them, the culture ends with that individual (Veidemann, 2011).

\section{Conclusion and recommendations}

Taking an integrated approach to curriculum development, especially with regard to the cycle of language subjects, in general comprehensive compulsory schools, meant for schooling of all population, and implementing it by means of engaging and coherent learning in wider and more supportive environments, can greatly enhance and improve students' achievement. The development of integrated $\mathrm{NC}$ is properly the responsibility of the government. Content learnt with comprehension allows students to become independent users of language with wide cultural horizons and the ability to understand diverse values in particular times and contexts. Integrated knowledge and skills enable them to become critically thinking individuals - responsible and informed citizens able to actively participate in different levels of social discourse. Meaningful and motivating learning leads to the development of an autonomous and self-aware personality; such individuals are able to shape their identities based on informed decision-making. Teachers as trusted intellectuals who have mastered the skills of organising integrated language learning based on linguo-didactic principles can create suitable learning content and environments at school level for all students regardless of their diverse learning strategies and styles. The aims and goals of education are still the same: making our schools acceptable to our students, meeting their personal needs and potential interests on the one hand, and imparting the necessary skills to manage their lives on the other. These aims and goals deserve further attention, both in theory and in practice.

\section{References}

Allardt, E. (1979). Implications of the ethnic revival in modern industrialized society. Helsinki, Finland: Societas Scientarium Fennica.

Balodis, P., Motivāne, K., \& Baltinšs, M. jt (2012). Language Situation in Latvia: 2004-2010. Research summary. Riga: Latviešu valodas aġentūra. http://www.valoda.lv/ downloadDoc_581/mid_522

Blommaert, J. (2006). Language Policy and National Identity. T. Ricento (Ed.). An Introduction to Language Policy: Theory and Method (pp. 238-254). Malden, Oxford, Victoria: Blackwell Publishing.

http://www.academia.edu/1410320/Language_policy_and_national_identity

Byram, M. S. (2008). From Foreign Language Education to Education for Intercultural Citizenship. Essays and Reflection. Clevedon: Multilingual Matters

Davies, T. (2014). Education and the 'International Dimension'. https://comeniuscitizenship. wikispaces.com/file/view/The+Global+dimension+and+international+education. 
Urve Lä̈̈nemets, Katrin Kalamees - Ruubel. Integrated Language Learning in Estonian National Curricula (Nc) for General Comprehensive Schools

European Commission. (2010). Europe 2020. A strategy for smart, sustainable and inclusive growth. Brussels.

Eysenck, M. W., \& Keane, M. (2005). Cognitive Psychology. A Students Handbook. Psychology Press, Taylor \& Francis Group, Hove and New York.

Holton, R. (2000). Globalization's Cultural Consequences, Annals of the American Academy of Political and Social Science, No. 570, pp. 140-152. http://www.jstor.org/ stable/i243186

Joseph, J. E. (2004). Language \& Identity. National, Ethnic, Religious. London: Palgrave MacMillian.

Kalamees-Ruubel, K. (2014). Eesti keele ja kirjandusõpetuse roll eesti õppekeelega üldhariduskooli õppekavas 1917-2014. Ajaloolis-analüütiline käsitlus. Doktoritöö. (The role of Estonian and literature in the curricula for general comprehensive schools (with instruction in Estonian) in 1917-2014. Historical-analytical approach. Doctoral thesis). Tallinn University, dissertations on social sciences 80, Tallinn.

Kalamees-Ruubel, K., \& Läänemets, U. (2012). Teaching Literature In and Outside of the Classroom. Procedia - Social and Behavioral Sciences 45, pp. 216 - 226. Elsevier, Helsinki. Available online at www.sciencedirect.com

Kampmann, M. (1918). Eesti keele õpeviis. Uuema aja pädagogika walgusesse seadnud M. Kampmann. Tallinn, G. P. Pihlaka kirjastus. The way of learning Estonian. (in Estonian)

Karseth, B., \& Sivesind, K. (2011). Conceptualising Curriculum Knowledge Within and Beyond the National Context. In: World Yearbook of Education 2011.

Krzyzanowski, M., \& Wodak, R. (2011). Political strategies and language policies: the European Union Lisbon strategy and its implications for the EU's language and multilingualism policy. Language Policy, Vol. 10, Iss. 2, pp. 115-136.

http://link.springer.com/article/10.1007\%2Fs10993-011-9196-5

Latvian Language Agency. (2005). Guidelines of the State Language Policy for 2005-2014. Riga: Talsu tipogrāfijā.

http://ec.europa.eu/education/literacy/about/countries/latvia_en.htm (30.11.2013)

Leino, A. L. (1979). Kielididaktiikka (in Finnish). Otava, Helsinki.

Lotman, J. (1990). Kultuurisemiootika. Semiotics of culture. (In Estonian) Tallinn: Olion.

Läänemets, U. (1995). Development of the content of education and curricula in Estonia (in Estonian). Tallinn, Jaan Tonisson Institute.

Läänemets, U., \& Kalamees-Ruubel, K. (2015). Content, identity building and national curricula. Society. Integration. Education. Proceedings of the International Scientific Conference May $22^{\text {nd }}-23^{\text {rd }}, 2015$. Vol II, pp. 114-124. Rezekne Higher Education Institution, Faculty of Education and Design. Rezekne, Latvia.

Läänemets, U. \& Valdmaa, S. (2015). CLIL in Estonia - present, past and future. Tartu University Press (in print).

Läänemets, U., Kalamees-Ruubel, K., \& Sepp, A. (1912). What makes a good teacher? Voices of Estonian Students. The Delta Kappa Gamma Bulletin. International Journal for Professional Educators, Vol. 79-1, pp 27-31.

Pring, R. (1976). Knowledge and schooling. Open Books, London.

Reinecke, W. (1985). Linguodidaktik. Zur Theorie des Fremdsprachenerwerbs. VEB Verlag Enzyklopädie, Leipzig.

Schiffman, H. (1995). Linguistic Culture and Language Policy. London: Routledge. 
Sepp, A. (2014). From music syllabi to teachers'pedagogical thinking: a comparative study of Estonian and Finnish basic school music education. Doctoral thesis. Faculty of Behavioral Sciences, Department of Teacher Education, Research Report 359,

University of Helsinki, Finland.

Slattery, P. (1995). Curriculum development in post-modern era. Garland Publishing, Inc. New York \& London.

Sowell, E. J. (2005). Curriculum. An Integrative Introduction. Upper Saddle River, New Jersey

Zimnjaja, I. A. (1978). Psihhologitsheskije aspekty obutchenija govoreniju na inostrannom jazyke. Prosvestchenije, Moskva (in Russian).

Veidemann, R. (2011). Praegu loetakse palju, kuid ei viitsita pingutada. (in Estonian) Postimees 24. 09. http://uudised.err.ee/index.php?06235244\&print=1 